The Transatlantic Trade and Investment Partnership (TTIP): a controversial agreement and dangerous for workers

Claude Serfati

Working Paper 2015.07 


\section{The Transatlantic Trade and Investment Partnership (TTIP): a controversial agreement and dangerous for workers \\ Claude Serfati}

Working Paper 2015.07

european trade union institute 
Claude Serfati is a former associate professor and PhD supervisor at the University of Versailles-Saint-Quentin-en-Yvelines (UVSQ) and former director of Cemotev (a research laboratory staffed by economists and geographers at UVSQ). He is currently an associate researcher at IRES (Institut de recherches économiques et sociales) and Cemotev.

This Working Paper is a translation from the French of the following article published in March 2015 by the Institut de Recherches Economiques et Sociales (IRES):

Serfati C. (2015) Le traité transatlantique : un accord controversé et dangereux pour les salariés, Chronique internationale de l'IRES, (149), 61-77.

http://www.ires-fr.org/images/files/Chronique/C149/C149-6.pdf

Translation from the French by Kathleen Llanwarne, ETUI

Brussels, 2015

๑ Publisher: ETUI aisbl, Brussels

All rights reserved

Print: ETUI Printshop, Brussels

D/2015/10.574/44

ISSN 1994-4446 (print version)

ISSN 1994-4454 (electronic version)

The ETUI is financially supported by the European Union. The European Union is not responsible for any use made of the information contained in this publication. 


\section{Contents}

Introduction .5

1. The controversial benefits of speeding up free trade ....................................................

2. Negotiations accelerated by the financial crisis .............................................................

2.1. A difficult geo-economic context for the United States and the European Union

2.2. A highly contested mandate and negotiating process.

3. Public procurement procedures and harmonisation of standards: some highly tense negotiations

3.1. Market access and non-tariff measures............................................................. 12

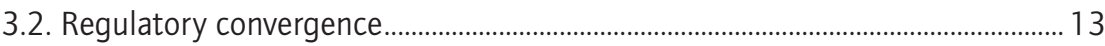

4. Disagreements on agriculture and environmental matters 16

4.1. Agriculture: a conflict-ridden topic ever since the creation of the WTO_......... 16

4.2. Divergence over the precautionary principle ......................................................... 17

5. The investor/state dispute settlement system: a new gold standard?

6. Trade unions: fears of social dumping............................................................................. 22

6.1. Concerns about wages and employment ............................................................... 22

6.2. Public services and public procurement procedures under threat...................... 23

7. Industrial and financial groups and European governments: some cracks in the common front

References 



\section{Introduction}

'There's a series of strategic, foreign policy and geo-political rationales for this particular negotiation. They may well be very significant in the broader scheme of things; in fact ... the strategic and the geo-political benefits may actually be

larger than the economic benefits.'

(Simon J. Evenett, quoted in NATO 2013)

The Transatlantic Trade and Investment Partnership (TTIP) 'is about the weight of the western, free world in world economic and political affairs'.

(Karel de Gucht, quoted in Emmott 2013)

'There are critical geostrategic reasons to get this deal done, and every day I am reminded of the global context of why we are negotiating TTIP.'

(Anthony L. Gardner, quoted in Vincenti 2014)

These statements, coming respectively from a leading academic specialist in world trade issues, from the EU chief negotiator to the TTIP talks, and from the US ambassador to the EU, throw light on aspects of what is at stake. TTIP is one component of a much broader cluster of initiatives, the overall thrust of which is to consolidate the geo-economic power of the 'transatlantic bloc' (US and EU). The expression 'economic NATO' has indeed been used to describe TTIP by the NATO Secretary General, by Hillary Clinton, former Secretary of State in the Obama Administration, and by many others. The expression is controversial, however, with some researchers pointing to the risk that it places too much stress on the idea of the West versus the rest of the world (Hamilton 2014). TTIP could represent one more step in the today highly contested domination of the 'transatlantic bloc' over the rest of the world. The agreement does not give rise to opposition in the world of labour alone; on some points, governments and industrialists are also divided over it.

The lay-out of this paper is as follows. Following this introduction, Section 1 addresses the controversial benefits of speeding up free trade and Section 2 provides some explanations for the speeding-up of negotiations between the US and the EU; the two following sections survey some controversial sectoral issues: public procurement and harmonisation of standards, agriculture and environment matters; Section 5 explains that the Investor/state dispute 
settlement is a key element of the discussion, strongly supported by transnational corporations and most governments; Section 6 focusses on the trade unions' fears that TTIP will set the scene for social dumping; Section 7 identifies some cracks in the common front of business and governments, a situation that could be exploited by trade unions and NGOs hostile to the project. 


\section{The controversial benefits of speeding up free trade}

The purpose of TTIP is the liberalisation of trade and investment in the transatlantic sphere. Though it would be very hard to find an expression that is more ambiguous than free trade, the concept forms the backbone of the dominant economic theories on which governments base their policies. Anyone entertaining doubts on this score might be persuaded by a reminder that international trade and foreign direct investment (FDA) are broadly controlled by the transnational corporations (TNCs) ${ }^{1}$. An extension of free trade therefore relates, first and foremost, to the intra-firm trade flows of goods and, above all, services, the circulation of which cannot be easily controlled by the regulatory authorities (customs, taxation), and which frequently form the prop or pretext for financial transactions or tax avoidance practices (Sauviat and Serfati 2015). All in all, therefore, the main beneficiaries of free trade measures are the TNCs.

Yet it is the advantages to be derived from a reduction of tariff and, above all, non-tariff barriers to free trade that serve as a justification for the TTIP negotiations. The European Commission, adopting an optimistic view of the benefits of free trade, does not hesitate to conclude that "the greater the extent of liberalisation proposed in the various policy options, the greater are the estimated welfare gains' ('estimated', that is, in the studies the Commission has had conducted for this purpose) (European Commission 2013a:50). The alleged virtuous circle is a simple one: the reduction of tariff and non-tariff barriers would be reflected in lower prices and these would stimulate exports. The increased export flows would in turn generate more economic growth and job creation in the countries concerned, but also in the importer countries thanks to the reduction in the prices of the goods and services purchased by consumers. The magnitude of these positive effects is dependent on a certain number of hypotheses, concerning, for example, the price elasticity of imports (by how much does a country increase its imports when the price of the products on offer falls?); or the gains and losses produced by a reduction in non-tariff barriers: the adoption of common regulations may result in a fixing of standards to the benefit of TNCs in possession of market power and hence act as a disincentive to other companies to pursue innovation (see Table 1, p. 10). The forecasts do refer to 'adjustment periods' during which some workers might lose out but such periods would, according to the Commission, be transitory.

1. In $2009,58 \%$ of goods imported by the United States from OECD countries were intra-TNC trade. Among German TNCs such trade accounts for $80 \%$ in the automobile industry, $76 \%$ in the chemical industry and 61\% in the capital goods industry (Felbermayr and Larch 2013). 
Simulations are frequently to be taken seriously only by those who have faith in them. Yet it is striking to observe that, even subject to the more optimistic hypotheses, the simulation models strain to come up with significant gains in growth, income and employment. When these are quantified, the level of benefits expected is likely to dampen the enthusiasm of TTIP advocates: the hardly breath-taking estimates arrived at by the Center for Economic Policy Research (François et al. 2013) of a 0.4\% GDP increase in the US and the EU were criticised as overoptimistic by outgoing European Commissioner Karel de Gucht. In France meanwhile, unlike the practice in other countries, no impact studies of this type have been commissioned by the Government.

These generous estimates of the effects of TTIP have been met with some degree of criticism (Raza et al. 2014 and, for agriculture, Berthelot 2013; CEPII 2014; Myant 2014). One study accordingly shows that TTIP would lead to net losses in exports, in growth in GDP, wages and employment, and in tax revenue, and that it would, furthermore, increase financial instability. The French economy, according to Capaldo (2014), stands to lose from this agreement.

Yet the North American Free Trade Agreement (NAFTA) signed among the United States, Canada and Mexico should serve as a warning. Studies published in the United States criticise the promises made by the agreement, which, according to the hype, was to have the effect of creating hundreds of thousands of new jobs and which, in actual fact, led to the loss of 700,000 jobs (Faux 2014). In reality, the most significant benefits expected from TTIP are essentially concentrated on increased trade flows, in other words, on TNCs. What is more, even studies favourable to TTIP mention significant sectoral differences: exports of engines and motor vehicles to the United States are expected to increase steeply, followed by agro-food products, insurance services, chemicals and financial services; meanwhile, a steep drop in exports of metal products, electrical machinery and transport goods is expected (The European House - Ambrosetti 2014). Finally, most studies fear negative effects for countries lying beyond the transatlantic sphere, in particular in Africa and Latin America (for a summary of studies and references to the negative effects for countries of the South, see Raza et al. 2014). 


\section{Negotiations accelerated by the financial crisis}

It is worth recalling the timetable and context that accompanied the launching of the TTIP negotiations. The aftermath of the collapse of the USSR saw a proliferation of statements in favour of a transatlantic partnership, and networks of large American and European TNCs were formed to act as major pressure groups in Washington and Brussels. As from 2007, however, the negotiations were significantly stepped up.

\subsection{A difficult geo-economic context for the United States and the European Union}

A whole set of factors served to exert pressure to speed up the discussions. First of all, the collapse of the Doha Round - launched in 2001 in the framework of the World Trade Organisation (WTO) - confirmed the difficulties dogging multilateralism that were prompting the United States and the EU to turn towards bilateral trade agreements. The financial crisis that broke out in 2007-2008 then hit these countries full-on and led to massive government intervention in various forms. While the major plans to support the financial sector in the US and EU are well-known, the proliferation of customs barriers has received less coverage. However, according to a report intended for the G2O - a grouping of the largest economies on the planet - these countries put in place, between October 2008 and May 2014, a total of 1185 protectionist measures (OECD and UNCTAD 2014). One aim of TTIP is, accordingly, to smooth over the most blatant differences between the biggest American and European TNCs and to create, as the expression goes, a 'level playing field'.

Another important factor is that the tightening of transatlantic links is taking place within a changing geo-economic context. This refers not only to the French return to NATO in 2007 and to this organisation's intervention in Libya, which marked the end of the George W. Bush unilateralist era. The financial crisis, having turned into a 'great recession"2, encouraged the US and EU to 'close ranks' in the face of increasingly strong competition from the emerging nations. Brazil and India are two countries that immediately come

2. Some economists now fear that the slowing of economic growth, and the weakness of productive investment in the majority of dominant and emerging countries, will turn into a case of 'secular stagnation', to use the expression coined by the Keynesian economist Alvin Hansen in 1938 to describe the economic situation of the United States in spite of the 'New Deal' brought in by the Roosevelt Administration. 
to mind, alongside Turkey which - while not invited to the discussions - will be required to apply the resulting treaty. China, against which another treaty currently under negotiation between the United States and the Pacific countries (the Transpacific Partnership) is partly directed, is, however, the main target of TTIP. At the end of the mandate given in 2011 to a working group of 'highlevel' European and American representatives and in the wake of the report prepared by them, the official negotiations were launched in 2013.

Table 1 Percentage world share taken by the United States and European Union in economic and financial activities

\begin{tabular}{l|l|}
\hline Production and trade activities & $\%$ (last year available) \\
\hline World GDP & $46(2014)$ \\
World trade & $47(2013)$ \\
\hline Financial activities & $85-89(2012)$ \\
\hline $\begin{array}{l}\text { Derived product markets } \\
\text { Bond markets }\end{array}$ & $55(2012)$ \\
\hline $\begin{array}{l}\text { Banking activities } \\
\text { Stock market capitalisation }\end{array}$ & $55(2012)$ \\
Household financial assets & $58(2013)$ \\
\hline Activity of transnational corporations (TNCs) & $83(2013)$ \\
\hline Number in UNCTAD Top 100 (based on current assets) & $55(2012)$ \\
World corporate R\&D expenditure & $70(2013)$ \\
Cross-border mergers and acquisitions & $71(2013)$ \\
Outgoing foreign direct investment &
\end{tabular}

\subsection{A highly contested mandate and negotiating process}

The negotiations were conducted between the European Commission and the US Trade Secretariat acting on behalf of the Obama Administration. The Commission, under the terms of the European treaties, is exclusively empowered to conduct negotiations on the EU's external trade (Article 3 of the Treaty on the Functioning of the European Union - TFEU). A French parliamentary report (Billout et al. 2014) points out, however, that the Commission is competent only within certain limits and that, in certain cases, agreements are 'mixed', i.e. concluded simultaneously by the EU and by its members. One of the problems is that the status of the two agreements currently under negotiation (CETA - Comprehensive Economic and Trade Agreement 
- with Canada ${ }^{3}$ and TTIP) has not been established; this raises additional questions since the Commission's negotiating mandate stipulates that the requirements laid down in the agreement will be binding on governments at all levels (Council of the European Union 2014:2).

The Commission has been criticised, what is more, for the way in which the negotiations have been conducted. The lack of transparency and the extreme 'discretion' that has surrounded the process have been observed by NGOs and trade unions as well as by members of the European and national parliaments. In France a report by the Senate denounces the 'opaque conduct' of the negotiations between the EU and Canada for the CETA as well as of those opened in June 2013 with the United States in the TTIP framework (Billout et al. 2014: 6). The European Commission has stated that it has registered these concerns and, on 9 October 2014, it made public the negotiating mandate that it had received on 17 June 2013. Yet the Commission continues to defend inclusion of the most contested points of the agreement, in particular the clause concerning investor/state dispute settlement (ISDS) ${ }^{4}$, even though the consultation that the Commission was obliged to conduct on the negotiations unequivocally revealed a strong degree of scepticism in relation to the ISDS mechanism, as declared by the European Trade Commissioner ${ }^{5}$. The Commission is not unaware of the strong opposition of the NGOs and trade unions. Insofar as it was the European Commission that received the negotiating mandate, the national governments are in a good position to adopt a cautious stance of non-committal. Even so, it is difficult to believe that they are in good faith, for powers have been vested in them by the electorates and yet they are allowing this clause to stand (see below).

On the US side, the federal system leaves considerable room for manoeuvre to the States and the Congress (House of Representatives and Senate). The government will request from Congress a mandate (in the framework of the Trade Promotion Authority) allowing it to use a simplified 'fast-track' procedure for consulting elected representatives on the negotiation (no amendments; limited period for consultation). The massive shift in Congress resulting in a Republican majority in the November 2014 elections complicates the situation even further. One of the major concerns expressed by the Commission and the European business interests derives, what is more, from the fact that the US States are free to choose whether or not to ratify the Treaty, and therefore to apply it or not, the salient point here being that the number of States that have actually implemented treaties ratified by the US Congress in recent years is rather small and continues to decrease.

3. The CETA, finalised in August 2014, is an agreement negotiated between Canada and the European Union. It too has been criticised by the trade unions and the NGOs because of the inclusion of an investor/state dispute settlement (ISDS) clause.

4. Karel De Gucht, European Trade Commissioner, warned that there will be no agreement between the United States and the EU if the ISDS clause is not included. 'De Gucht warns EU that US May Cut Off Free-Trade Talks', Jonathan Stearns, BloombergBusiness, 2 October 2014.

5. J. Stearns 'EU Cites Unease on Investment Clause in US Trade Pact', BloombergBusiness, January 13, 2015 . 


\section{Public procurement procedures and harmonisation of standards: some highly tense negotiations}

The negotiating mandate provides for three major 'chapters':

- market access (reduction in customs dues and opening-up of public procurement procedures);

- regulatory cooperation or convergence (in the areas of health, environment, financial activities, etc.) and non-tariff measures (NTM);

- rules (status of state enterprises, energy policy, state/investor conflict, etc.).

\subsection{Market access and non-tariff measures}

The transatlantic area is characterised by a high degree of integration: flows of capital and goods are intensive, accompanied by a strong mobility of persons. The customs dues in force between the United States and the EU are generally quite low and certainly much lower than in other regions of the world. According to the European Commission, customs dues levied amount in the case of the EU to $5.2 \%$ and in that of the US to $3.5 \%$. The levels of weighted customs dues - which take into account the effects of actually occurring trade flows - are significantly closer, namely, $2.8 \%$ (import duties on US products entering the EU) and 2.1\% (import duties on European products entering the United States ${ }^{6}$.

However, this moderate average level of customs dues conceals some startling disparities. Nor do the two sides to the negotiations agree on the level of these obstacles to trade. On the European side the highest customs duties are for lorries (22\%), footwear (17\%), audio-visual products (14\%) and clothing (12\%). On the American side, the dues on agricultural products are lower, with the notable exception of tobacco (350\%) - as well as of footwear (56\%) and clothing (40\%).

Another significant aspect under this first chapter is the thorny question of the opening-up of public procurement procedures. In spite of all the discourse about free trade, protection of public contracts remains a major industrial policy instrument. At the demand of several countries, and above all the United States and France, defence markets have been excluded from the negotiations

6. WTO website: http://stat.wto.org/TariffProfiles/US_e.htm 
(on the major role played by the defence industry in France, see Serfati 2014). Public contracts represent a significant share of GDP, estimated at an average of $16 \%$ in the EU as a whole but being in some member states as high as $25 \%$ of GDP (European Commission n.d.). In the United States, according to OECD figures, federal contracts alone accounted for 11\% of GDP in 2011 - two thirds of these being defence contracts - to which must be added public contracts in the individual States. The opening up of public procurement accordingly constitutes a major apple of discord that is unlikely to be overcome to any significant extent.

The second chapter of the proposed treaty deals with 'non-tariff measures' (NTM) which, according to the WTO, need to be specified with greater precision in order to facilitate market access. These constitute the main forms of protectionism in transatlantic trade as well as, quite certainly, further afield. It is in this area that the greatest benefits are expected. According to several studies, between two thirds and four fifths of the gains to be derived from a future transatlantic agreement would result from the reduction of bureaucracy and the strengthening of coordination among regulatory authorities (European Commission 2013).

\subsection{Regulatory convergence}

Non-tariff measures (NTM) are, according to studies conducted on behalf of the Commission, implemented at frontiers (customs procedures, etc.) and also - in the newspeak of international diplomacy - 'behind the frontiers' (i.e. in the form of laws, regulations and practices) (Berden et al. 2009). Measurement of their extent and of the benefits to be derived from their reduction is difficult and is based on undeniably normative criteria, in particular when it comes to distinguishing between what are 'good' and what are 'bad' rents'.

What is more, the studies of NTMs carried out on behalf of the Commission are essentially based on the surveys conducted in 5500 companies whose management has been invited to offer an opinion on the level of non-tariff barriers (Plaisier et al. 2013: 34). These surveys cover matters such as health and plant-health measures, standardisation rules and procedures. Although the European Commission acknowledges the difficulties of measuring such barriers and the economic effects of eliminating them, a study dating from 2007 - commissioned by it and which serves as a basis for the current negotiations - estimated that $50 \%$ of non-tariff barriers could potentially be eliminated or, under a more modest scenario, 25\%. Discarding the aforementioned difficulties of measurement, estimates show that NTMs play a significant role

7. According to studies conducted on behalf of the Commission, "in case of an increase in market concentration, consumer prices may also go up. However part of the increase is then appropriated by companies as they reap increased revenues and profits. Thus there is a redistribution of welfare, and not simply a reduction in economic efficiency' (François et al. 2013: 16). These then are taken to be 'good rents'. Action taken by workers or farmers in an effort to preserve their acquired rights will, on the other hand, be regarded as 'bad rents'. 
in relation to specific sectors and products. Taking the scenario consisting of a more limited agreement ${ }^{8}$, EU exports would increase between now and 2027 by $1.53 \%$ and EU imports by $1.31 \%$, while the results would be slightly higher for the US (respectively $2.23 \%$ and 1.84\%) (CEPR 2013: 36).

The regulations in place on both sides of the Atlantic are regarded by the Commission as resulting - in spite of their differences - in an equally high level of safety. The Commission's call is thus for 'regulatory convergence' which is a rather vague formula that could, depending on the sectors of industry concerned, take the form of a harmonisation of legislation, of an approximation of different legislations, of mutual recognition, or of the issuing of 'equivalences'.

Here are some examples of some differing regulations currently to be found in the motor car industry. This is a sector which, in spite of the increasing presence of foreign manufacturers on the national markets, nonetheless remains less open than other consumer goods industries (such as electronics, furniture, etc.). NTMs serve to protect national manufacturers, while consumers continue to exhibit a strong preference for models produced in their own country. Even so, the rules and regulations in force do also raise - to the advantage of local producers - significant barriers to full competition. Though environmental or safety standards may be regarded as being of a comparable level, they differ nonetheless so that a vehicle compliant with all the standards on one side of the Atlantic will not be authorised for sale on the other side without changes in design, giving rise to additional costs to be borne by the manufacturers and distributors and - ultimately - the consumers. Thus the specific safety requirements in the EU and the United States for lights, doorlocking, brakes, steering, seats, safety belts and electric windows are, while resulting in comparable levels of overall safety, currently different in respect of their details.

Anti-pollution standards arealso different. The US authorities usemeasurement of petrol consumption for a given distance, whereas the standards devised by the European authorities are based on $\mathrm{CO} 2$ emissions - measured in grams - from exhaustion pipes. The problem of comparability is exacerbated, what is more, by the fact that the test cycles adopted by the US and the EU to check manufacturers' compliance with standards differ in several respects (average speed of vehicle, over time, distance, acceleration and deceleration, etc.) and all these factors significantly affect the results. Moreover, an idea of the challenge represented by regulatory convergence can be gained from the fact that the attempts already made in 1996 on the basis of proposals drawn up by American, European and Japanese automobile manufacturers in relation to different components (including windscreen wipers, defrosting systems, and safety belts) ended in a complete refusal on the part of the regulatory authorities which considered it too difficult, if not impossible, to establish any

8. Elimination of $90 \%$ of customs duties, of $10 \%$ of non-tariff barriers in services and of $25 \%$ in public procurement (CEPR 2013: 27). 
functional equivalent among the differing standards in question (Canis and Lattanzio 2014).

Other sectors, such as chemicals, pharmaceuticals, and of course agriculture (see below) are also subject to some extremely tense discussions on standardisation issues. 


\section{Disagreements on agriculture and environmental matters}

As it is impossible in the space of this article to deal with the full range of disagreements, two areas will be discussed by way of example: agriculture and environmental questions.

\subsection{Agriculture: a conflict-ridden topic ever since the creation of the WTO}

Agriculture is one of the most important chapters and has always been among the most conflict-ridden topics in the international trade negotiations conducted within the WTO framework. Agricultural questions had, moreover, been explicitly excluded from the competence of the WTO's forerunner, the General Agreement on Tariffs and Trade (GATT), created soon after the end of World War II. Agricultural production does indeed raise, over and above its economic importance, numerous social and environmental challenges the scope of which can be only very partially measured by the discussions on standards and regulation. This aspect was reiterated by the representative of the US Agriculture Department when reporting on complaints from other industrial sectors of the US economy that in the United States agriculture contributed $20 \%$ to supporting the economy while claiming $80 \%$ of political support (House of Lords 2014:44). American producers enjoy, from the outset, the 'exchange rate' advantage which is used as a weapon in competition ${ }^{9}$ (Pouch 2014).

Two aspects well illustrate the complexity of the negotiations: the plant health measures and the 'geographical indications ${ }^{10}$. The commonplace-sounding expression 'geographical indications (GIs)' used to refer to the label that states a product's place of origin does not successfully mask the decisive importance of this information and concept. By way of example, wine, beer and cheese for which a label of origin is obviously required - account for more than half of French exports to the USA. American agro-food companies, meanwhile, currently produce 'parmesan', 'munster', 'feta' and many other European cheeses, as well as 'European' wines. Some British MPs have stressed the importance of protecting the labels 'Scotch beef', 'Scotch lamb', 'Welsh beef', 'Welsh lamb' and 'West Country farmhouse cheddar', while the stance of the National Farmers' Union (NFU) is close to the US positions.

9. American exports generally react very favourably to the depreciation of the dollar. 10. On the question of GMOs, see Friends of the Earth (2014). 
The EU is demanding a ban on sales of such products under these names in the United States if they are manufactured there, in order to uphold the notion and value of GI (Appelation d'Origine Contrôlée, Appelation d'Origine Protégée, etc.). The US government, at the demand of industry, is rejecting this demand, claiming that the names parmesan, camembert and many other such labels designate, for the American consumer, a generic product ${ }^{11}$. According to the former European negotiator, acceptance by the United States of the GI could serve as a bargaining counter to be exchanged for the opening up of the European meat (beef, pork) and poultry markets to American products (House of Lords 2014: 46).

The divergences on plant-health measures have been reported in the media, giving rise to European consumer concerns and fears of having to eat USproduced chicken that has been cleaned using chlorine. While it is true that the increase in exports of US meat and poultry constitutes, with the question of GMOs, the United States' main entry point in this sector, this example nonetheless risks diverting attention from matters deserving of much deeper concern. Thus the draft agreement stipulates that exports of agricultural produce must comply with the 'appropriate level of protection of the importer country'. In practice, this would require the European negotiators to adopt a case-by-case approach to the products for which they are demanding exemption in the transatlantic agreement. And yet, to take the example provided in a very well documented report (Suppan 2014), the setting of a threshold for the maximum pesticide residue in cereal imports, or of veterinary products in meat imports, is a matter concerning which it is very difficult for the European consumer to obtain information, since the information supplied to the American regulatory body is in large measure subject to trade secrecy. The alternative approach, one that would consist in getting international organisations to set authorised thresholds, is no better, for these are, like the Codex Alimentarius Commission referred to in TTIP, broadly dominated by the agro-food industry. Any regulatory measures adopted through such channels would be highly unlikely to favour consumer interests.

\subsection{Divergence over the precautionary principle}

The question of the environment is also hotly debated. The European Commission has openly acknowledged that TTIP will have the effect of stepping up pressure on the environment which, according to an impact study that it has commissioned, will endanger both natural resources and the preservation of biodiversity (quoted in Hilary 2014: 21). The precautionary principle which prevails in Europe has been long contested by some European industrialists who regard it as an excessive and unfair burden in international competition. It requires them to prove that a product that they wish to commercialise is not dangerous. They accordingly hope that a transatlantic agreement will serve

11. It is to be noted, even so, that a few American producers, those of the famous wines from the region of Napa or of Kona coffee (from Hawaii), are also demanding respect of the GI. 
to water down the scope of the principle as currently applied in Europe. The prevailing principle in the United States is that of 'sound science' which enables less stringent rules and standards to be laid down in the environmental sphere. According to the US trade unions (American Federation of Labour - Congress of Industrial Organisations - AFL-CIO), the expression 'sound science' is nothing but a code word used to dispense with the need for protection (House of Lords 2014).

In total, assuming a $25 \%$ reduction in non-tariff barriers and the complete abolition of customs dues, by 2025 transatlantic international trade would increase by $40 \%$. The effects on the agro-food sector would be greater than this, but also highly unbalanced. Between now and 2025, exports from the EU to the US would increase by $60 \%$ and those from the US to the EU by 120\% (CEPII 2014: 11). France is the number one European exporter of agricultural produce and agro-food products to the rest of the world, ahead of the Netherlands, Germany, Italy and Spain; France is also the country with the highest trade surplus. As for other European countries, the effects of an agreement on the creation of added value in this sector would be negative, with a particular impact on certain meats (pork, chicken), cereals and fruit (CEPII 2014: 43). It is unfortunately likely that the farmers in developing countries will be the victims of this agreement, just as they are of the economic partnership agreements that promoted free trade between the EU and most of the African former colonies. 


\section{The investor/state dispute settlement system: a new gold standard?}

The investor/state dispute settlement (ISDS) system is beyond any doubt the most controversial measure in TTIP. Before opposition to this clause began to gather to the point where its implementation appeared jeopardised, the Commission had boasted 'a new departure for investment and investment protection' (European Commission 2013b). In essence, this system, which has been in existence for decades (Weaver 2014), offers an investor direct recourse for complaint, in a private international jurisdiction, against the authorities of the country where the investment is being made. Grievances may be reported if an investor considers that he is the victim of discrimination; of expropriation for reasons other than public policy goals and in the absence of fair compensation; of unjust or unfair treatment; or of measures that prevent him from transferring capital.

TNCs and consultants (in particular legal advice services) on both sides of the Atlantic strongly support the adoption of an ISDS clause in the transatlantic agreement. Its inclusion in TTIP would seem at first sight unnecessary insofar as the legal advice and litigation systems are highly developed on both sides of the Atlantic and offer investors very high levels of protection. The multinationals are nonetheless in favour of this proposal, for two main reasons. On the one hand, they place greater trust in private arbitration than in the state courts, an opinion which, on the basis of a stock-taking of the current operations of ISDS systems, appears justified. On the other hand, the geo-economic dimension is fundamental here. Taking account of the place of the transatlantic sphere in the world economy, the inclusion of this mechanism in TTIP would in practice compel its adoption by the rest of the world, and in particular by the emerging countries. It has been stated by a recognised representative of the business world that an ISDS clause (in TTIP) would amount to a gold standard ${ }^{12}$ which would then serve as a precedent in subsequent negotiations (Goldsmith 2014: 90) with other countries and regions of the world. The same formula is used by the former US Deputy Trade Secretary responsible for investment. It may be worth adding that this type of jurisdiction would be of benefit to American firms which have been long accustomed to procedures of this type.

12. This refers to the 'gold standard' that served as a basis for the international monetary system during the $19^{\text {th }}$ century and up until 1914. It enabled exchange rate stability in contrast with the strong instability that has characterised exchange markets over the last forty years. 
The ISDS system is today present in virtually all (93.5\%) of the 1660 bilateral trade and investment agreements inventoried by the OECD in 2012. Its use has enjoyed growing success since the beginning of the 2000 s with a cumulative total of 568 complaints recorded by the end of 2013 worth a total of 200 billion dollars, whereas only around fifty such cases had been filed since the $1950 \mathrm{~S}$ (UNCTAD $2013^{13}$ ). Taking only the trade agreements signed by the United States, 'more than 14 billion dollars remains pending in corporate claims against medicine patent policies, pollution clean-up requirements, climate and energy laws, and other public interest policies' (Public Citizen 2014). The vast majority (85\%) of these complaints come from developed country investors (75\% of them from the EU and the US) as against $13 \%$ of complaints from developing countries and $2 \%$ from transition countries. On the other hand, it is countries other than the EU and the US that constitute the very great majority of the investors' targets. The most frequently invoked grounds for complaint relate to cancellation of licensing agreements, direct or indirect expropriation, measures taken to stem the financial crisis, environmental and public health measures, tax measures (UNCTAD 2013).

The EU has frequent recourse to this procedure; its countries account for $53 \%$ of the overall total of complaints registered. Among EU member states the Netherlands (21\% of complaints registered by EU countries), the United Kingdom (14\%), Germany (13\%) and France (10\%) are the main users. Almost $30 \%$ of the complaints made by European investors are directed against other European countries and, in the vast majority of cases, transition countries, a sure sign of a still very unequal situation prevailing between the 'core' EU member states and the new member states. The TNCs from the heartlands of Europe invest in - and frequently relocate to - these countries in order to take advantage of their skilled and low-paid manpower while having recourse to action in private courts in order to contest measures taken by these countries' governments (see Box below). 


\section{Nationalisations, health, labour law and environment subject to attack in ISDS}

A few examples that bear witness to the powerful influence of ISDS*:

Nationalisation: there have been several cases of legal action taken by companies following government action that resulted in a reduction of their company's 'expected profits' and which they regard, depending on the case, either as 'indirect expropriation' or as violations of the 'rules on minimum treatment guarantees', a clause that allows them to take out legal proceedings against governments. Thus, in 2012 the Argentine government took control of a subsidiary of the Spanish oil group Repsol, claiming that the group was repatriating its profits made in Argentina in order to invest them elsewhere, leading to a drop in production. The Repsol directors retorted that the reduction in exploration of new oil fields and the drop in production were the result of export and price controls exercised by the Argentine government.

Social: in 2012 the French group Veolia took out proceedings against the Egyptian government. Its complaint related to the impossibility of passing on in its fuel tariffs the increased labour costs (particularly an increase in the minimum wage). It had signed a contract with the city of Alexandria that protected it against any increase in wages.

Health: the Philip Morris group took out proceedings against the Australian government following its decision to introduce plain packaging for all tobacco products.

Environment: the Swedish firm Vattenfall took out a case against the German government following the latter's decision, after the Fukushima disaster, to halt its nuclear programme. In Quebec the Lone Pine energy company attacked the Canadian government over its decision to ban hydraulic fracturing (moratorium on shale gas).

* For an analysis of ISDS see CEO (2014) and Public Citizen (n.d.) 


\section{Trade unions: fears of social dumping}

The trade unions, frequently in association with the NGOs, have drawn up a list of points that appear to them to directly threaten workers' interests (ETUC 2013; ETUC/AFL-CIO 2014). What they fear is that the search for harmonisation and mutual recognition of rules and standards, which is a central feature of the negotiations, will translate into a downward spiral of worsening standards and lead to social dumping.

\subsection{Concerns about wages and employment}

On the one hand, the large American and European multinationals are divided, sometimes between one industry sector and another or even within the same sector (see below the example of the French automobile industry). On the other hand, they are prepared to form a common front to implement measures intended to minimise their production costs and lessen their regulatory constraints. The British trade union GMB (more than 620,000 members across a wide range of sectors, both public and private), well informed on the state of labour relations in the US, considers that this agreement represents a 'very real risk that hard won labour and employment rights in Europe will be forced down to the frequently far lower level of American labour rights' (House of Lords 2014:80). A process of downward harmonisation is all the more feared by the trade unions in that the United States has not ratified six of the eight ILO fundamental rights (forced or compulsory labour, absence of pay discrimination, minimum age of work, etc.). This is why UNITE, the largest UK trade union (1.5 million members) is asking the European Commission to call on the United States to ratify in full the ILO conventions as a condition of the TTIP negotiations (House of Lords 2014: 171).

The dangers for workers come also from the Commission and the connections it might well see fit to establish between TTIP and the European REFIT programme. While the Commission states that the aims of REFIT are to reduce regulatory costs and to simplify administrative procedures in Europe, the programme stands ready to serve as an instrument for the implementation of TTIP and its threatened onslaught on the health and safety of European workers (Ponce del Castillo 2015). 
Some American trade unionists refer to NAFTA which they claim has entailed high employment costs but also a deterioration of working conditions for American workers. They have accordingly issued a warning to their European counterparts, pointing out that the United States is, in the case of TTIP, the low-wage signatory, contrary to the situation in the other trade agreements that this country has been accustomed to conclude; and it is indeed true that wages are generally lower in the United States than in the majority of European manufacturing industries. If such an agreement were to be signed, the United States would become the 'Mexico of Europe' because of the low wages paid in the country's southern States.

\subsection{Public services and public procurement procedures under threat}

Public services are under threat from the agreement because the 'negative list' principle is likely to be applied; in other words, only services explicitly named in the agreement will be able to be saved from privatisation and opening up to or strengthening of competition. The European Trade Union Confederation, meanwhile, gives precedence to the opposite principle of the 'positive list', which consists in listing explicitly and exclusively the types of service that are open to privatisation. Such a rule would require the reopening of negotiations at each new attempt to call a public service into question (ETUC 2013).

The American and European trade unions oppose the inclusion of public procurement in the negotiations. Protection of public contracts is defended on grounds of employee status (public sector workers generally enjoy better protection than those in the private sector), in terms of quality of services supplied (insofar as the goals of user satisfaction take priority, in principle, over considerations of profitability), and, finally, because the provision of public services is an essential plank of public policy rather than a market to be opened up, as stressed by the AFL-CIO. The threat to the National Health Service is acutely perceived in Great Britain in particular but other health systems could be affected also ${ }^{14}$. Recourse to ISDS would allow investors to initiate legal proceedings to attack measures taken by governments and that could be regarded as a direct or indirect assault on their interests. The condemnation of the Slovak government following a complaint by Dutch insurance groups seems to justify this fear that has been further inflamed by a letter from the European negotiator acknowledging that health services do indeed form part of the negotiations. The British trade unions are calling for the official exclusion of public health services from the TTIP negotiations, along the same lines as the exclusion of audio-visual questions obtained by the French government.

14. See the position adopted by several NGOs 'Joint Response to the Public Consultation on Investment Protection and ISDS in TTIP : The inclusion of investor-to-state Dispute Settlement (ISDS) in the Transatlantic Trade and Investment Partnership (TTIP) Would Undermine Public Health', Brussels, July 112014. 
Some trade unions (including IG Metall and other members of the Deutscher Gewerkschaftsbund - DGB, of the Confederazione Generale Italiana del Lavoro - CGIL, of the French CGT, of the Comisiones Obreras - CCOO, and of the UGT of Catalonia) have adopted an even more militant position. Trade unionists thus demand the suspension of the TTIP negotiations in favour of other measures aimed at harmonising environmental, labour and consumer standards at the highest existing level. 


\section{Industrial and financial groups and European governments: some cracks in the common front}

The governments and large European firms are obviously in favour of the conclusion of TTIP insofar as it is they who promoted the idea of an agreement of this type. The TNCs, organised in highly influential networks, some of them deliberately formed to exert influence in the framework of the TTIP negotiations, are developing convergent positions on a wide range of subjects. The lowering of customs duties and the opening-up of public procurement are proposals that enjoy broad support, and the ISDS system is generally highly favoured ${ }^{15}$. It would nonetheless be a mistake to believe in the existence of a consensus among all the large American and European companies in a context where tough competition on the markets is exacerbated by the currently weak economic growth and the arrival of large firms from the emerging countries. Behind the harmonisation of standards some covert battles are being waged. In the automobile industry, German and British firms are formally pushing for an agreement from which they would stand to gain a great deal. The French automobile manufacturers, on the other hand, have stated their hostility to such an agreement because they do 'not believe they could benefit from mutual recognition of standards and consider that their European competitors would be the real beneficiaries of an agreement' (Ministère du commerce extérieur 2013); this stance is a way of acknowledging their weak presence on the American market and their fear of the free trade that they are usually so prompt to invoke in the face of demands from labour. The automobile parts manufacturers present in France, as well as Toyota, are, meanwhile, in favour of TTIP.

Nor do the positions adopted by European governments present a homogeneous front. The most striking example in this respect relates to the ISDS system. Initially, the French government, aware of the broad opposition to this system, had appeared to come out against its inclusion in the agreement ${ }^{16}$. However, the recent Franco-German statement (21 January 2015), published after the results of the Commission consultation, refers only to 'a new phase to conduct exchanges on improvements to be made to ISDS'. Similarly, the German coalition, divided between Christian democrats and social democrats, was initially opposed to this clause until a significant about-turn by the social

15. It is to be noted, nonetheless, that in Germany the large firms are very much in favour of the ISDS whereas the association of SMEs has unequivocally expressed its hostility.

16. Madame Marie-Noëlle Lienemann : 'It seems therefore to me that we should immediately tell our partners that we will refuse to ratify an agreement that provided for the inclusion of an investment/state dispute settlement mechanism of this type. - Madame Nicole Bricq, minister. This is what we have said!' Senate, session of 9 January 2014, http://www.senat. fr/seances/s201401/s20140109/s20140109003.html 
democrat Sigmar Gabriel, minister for economic affairs and energy, made it seem that the government would accept this clause in exchange for concessions in other areas, doubtless the automobile and chemicals industries. The Obama Administration too is in favour of this clause, reflecting extremely pro-bigbusiness views, while, according to declarations from the AFL-CIO, Congress appears more divided, with a third of members supporting their own position, a third firmly in favour of ISDS, and a third still wavering.

The front formed by the governments, like that of the multinational companies, thus reveals cracks on certain topics, even if the general aims are shared. This is a situation that could be exploited by trade unions and NGOs if they were to demonstrate their joint opposition to a project which will, from their standpoint, worsen their working and living conditions; they could, in this way, seek to prevent an agreement (Husson 2014). The TTIP undoubtedly represents a kind of general framework that is likely to remain in place so that, even if the current negotiations were to result in no more than a partial agreement, this is a subject bound to remain on the agenda. 


\section{References}

Berden K.G., Francois J., Thelle M., Wymenga P., Tamminen S. (2009) Non-tariff measures in EU-US trade and investment - An economic analysis, Reference OJ 2007/S180-219493, Final Report, Rotterdam, Ecorys Netherland BV.

Berthelot J. (2013) La folie d'intégrer l'agriculture dans un accord de libre-échange transatlantique UE-USA, Solidarité, 21 août.

Billout M. (2014) Rapport sur le règlement des différends entre investisseurs et États dans les projets d'accords commerciaux entre I'Union européenne, le Canada et les États-Unis, $n^{\circ} 134$, Sénat, 27 novembre.

Canis B., Lattanzio R.K. (2014) US and EU motor vehicle standards: issues for Transatlantic Trade Negotiations, February 18.

Capaldo J. (2014) The Transatlantic Trade and Investment Partnership: European disintegration, unemployment and instability, GDAE Working Paper, $n^{\circ}$ 14-03, October.

CEO (2014) TTIP: Debunking the business propaganda over investor rights, July 3, http://corporateeurope.org/international-trade/2014/07/ttip-debunking-businesspropaganda-over-investor-rights

CEPII (2014) Risks and Opportunities for the EU Agri-food sector in a possible EU-US Trade Agreement, Research Report, no 2014-01, September.

Corporate Europe Observatory (2014) Debunking the business propaganda over investor rights, July 3, http://corporateeurope.org.

Council of European Union (2014) 11103/1/13, REV 1 DCL 1 (fr), Brussels, Iscet, 9 October.

Emmott R. (2013) EU trade chief hopes to clinch US trade by late 2014, Reuters, February 27, http://uk.reuters.com/article/2013/02/27/us-euro-summit-tradeidUKBRE91Q0QM20130227

ETUC (2013) ETUC position on the Transatlantic Trade and Investment Partnership, 25 April. https://www.etuc.org/documents/etuc-position-transatlantic-trade-and-investmentpartnership\#.VZTzO_ntlBc.

ETUC/AFL-CIO (2014) Declaration of joint principles ETUC/AFL-CIO. TTIP must work for the people, or it won't work at all, July 8.

European Commission (2013) Le partenariat transatlantique sur le commerce et l'investissement: le volet réglementaire, September.

European Commission (2013a) Impact assessment of the future of EU-US trade relations, Commission Staff Working Document, SWD(2013) 68 Final, March 12, http://trade. ec.europa.eu/doclib/docs/2013/march/tradoc_150759.pdf.

European Commission (2013b) Protection des investissements et règlement des différends entre investisseurs et États dans les accords de I'UE, Fiche d'information, November.

European Commission (n.d.) website Trade. http://ec.europa.eu/trade/policy/accessingmarkets/public-procurement 
Faux J. (2014) NAFTA, twenty years after: a disaster, Huffington Post, January 1st, http://www.huf fingtonpost.com/jeff-faux /naf- ta-twenty-years-after_b_4528140.html

Felbermayr G.J., Larch M. (2013) The Transatlantic Trade and Investment Partnership (TTIP): Potentials, problems and perspectives, CESifo Forum 2/2013, p. 49-60.

Francois J., Manchin M., Norberg H., Pindyuk O., Tomberger P. (2013) Reducing Transatlantic Barriers to Trade and Investment - An economic assessment, Final Project Report, London, CEPR.

Friends of the Earth Europe (2014) GM food and the EU-US trade deal, Brussels, Friends of the Earth Europe.

Goldsmith (Lord) QC (2014) Supplementary written evidence, in House of Lords, European Union sub-committee on external affairs. Transatlantic Trade and Investment Partnership Written Evidence Volume, p. 90-93, March 21.

Hamilton D.S. (ed.) (2014) The Geopolitics of TTIP: Repositioning the Transatlantic Relationship for a changing world, Washington DC, Center for Transatlantic Relations.

Hilary J. (2014) The Transatlantic Trade and Investment Partnership (TTIP). A Charter for deregulation, an attack on jobs, an end to democracy, Brussels, Rosa Luxemburg Stiftung.

House of Lords (2014) The Transatlantic Trade and Investment Partnership, European Union Committee, Fourteenth Report of Session 2013-14, London, The Stationery Office Limited.

Husson M. (2014) Pourquoi il faut bloquer le Transatlantic Free Trade Area, À l'encontre, 26 novembre. http://alencontre.org/ameriques/americnord/usa/pourquoi-il-fautbloquer-le- transatlantic-free-trade-area-tafta.html

Ministère du Commerce extérieur (2013), Europe/États-Unis : les entreprises françaises sont majoritairement favorables à un accord de partenariat transatlantique, équi- libré et facteur de croissance et d'emplois, Communiqué de presse, $n^{\circ} 213,25$ mars.

Myant M. (2014) The Transatlantic Trade and Investment Partnership: exaggerated hopes from the liberalising agenda?, Policy Brief no 4. Brussels, ETUI.

NATO (2013) NATO Parliamentary assembly debates trans-atlantic trade talks; http://www. nato-pa.int $/$ default.asp?CAT2 $=3292 \& C A T 1=3109 \& C A T 0=578 \& C O M=3292 \& M O D=0$ $\& S M D=0 \& S S M D=0 \& S T A=0 \& I D=0 \& P A R=0 \& L N G=0$ Dubrovnik, 12 October 2013.

OECD, UNCTAD (2014) Eleventh Report on G20 trade and investment measures, June 16.

Plaisier N., Mulder A., Vermeulen J. (2012) Study on EU-US High Level Working Group, Final Report, Rotterdam, Ecorys Netherland BV.

Ponce del Castillo A.M. (2015) TTIP: fast track to deregulation and lower health and safety protection for EU workers, Policy Brief no 1/2015, Brussels, ETUI. https://www.etui. org/fr/Publications2/Policy-Briefs/European-Economic-Employment-and-Social-Policy/ TTIP-fast-track-to-deregulation-and-lower-health-and-safety-protection-for-EU-workers

Pouch T. (2014) Grand Marché Transatlantique : Un objectif : circonscrire la puissance chinoise, Chambre d'agriculture, (1034), p. 9-12. http://www.chambres-agriculture.fr/ fileadmin/user_upload/Revue/Article/Revue_1034/1034_Marche_Transatlantique. pdf

Public Citizen (2014) Tens of thousands of US firms would obtain new powers to launch investor-state attacks against European policies via CETA and TTIP, Washington DC. https://www.citizen.org/documents/EU-ISDS-liability.pdf

Public Citizen, Economic Policy Institute, Coalition for Sensible Safeguards, US PIRG, Sierra Club, CFA, Center for Effective Government (n.d.) TAFTA: Empowering Corporations to Bypass Domestic Courts and Attack Consumer and Environmental Safeguards before Extrajudicial Tribunals. http://www.foreffectivegov.org/files/regs/TAFTA-investor-statefactsheet.pdf 
Raza W., Grumiller J., Taylor L., Tröster B., von Arnim R. (2014) ASSESS_TTIP. Assessing the Claimed Benefits of the Transatlantic Trade and Investment Partnership, Final Report, Vienna, Austrian Foundation for Development. http://www.guengl.eu/uploads/plenaryfocus-pdf/ASSESS_TTIP.pdf

Sauviat C., Serfati C. (2014) Emprise financière et internationalisation des groupes industriels français : un premier état des lieux, La Revue de I'IRES, (82).

Serfati C. (2014) L'industrie française de défense, Paris, La Documentation française.

Suppan S. (2014) Analysis of the Draft Transatlantic Trade and Investment Partner- ship (TTIP) chapter on food safety, and animal and plant health issues (Proposed by the European Commission, as of June 27, 2014) July 23. http://www.iatp.org/documents/ analysis-of-the-draft-transatlantic-trade-and-investment-partnership-ttip-chapter-on-food.

The European House - Ambrosetti (2014) The EU-US Transatlantic Trade And Investment Partnership. Re-launching Europe's Competitiveness, September 5-6-7. file:///C:/Users/ gcorda/Downloads/140906_TIIP\%20Scenario_DEF.pdf.

UNCTAD (2013) Recent Developments in Investor-State Dispute Settlement (ISDS), Issues Notes, $n^{\circ}$ 1, May. http://unctad.org/en/PublicationsLibrary/webdiaepcb2013d3_ en.pdf.

Vincenti D. (2014) US Ambassador: beyond growth, TIP must happen for geostrate- gic reasons, Euractiv, July 16. http://www.euractiv.com/sections/trade-industry/usambassador-eu-anthony-l-gardner-beyond-growth-ttip-must-happen

Weaver M. (2014) The Proposed Transatlantic Trade and Investment Partnership (TTIP): ISDS Provisions, Reconciliation, and Future Trade Implications, Emory International Law Review, 29(1), 225-275. 



\section{ETUI Working Papers}

Free movement of labour in Europe: a solution for better labour allocation?

Working Paper 2015.06

Béla Galgóczi and Janine Leschke

Beyond the CEE 'black box': crisis and industrial relations in the new

EU member states

Working Paper 2015.05

Magdalena Bernaciak

"Better Regulation": a bureaucratic simplification with a political agenda Working Paper 2015.04 / EN, FR

Éric Van den Abeele

Spain's labour market reforms: the road to employment -

or to unemployment?

Working Paper 2015.03

Laszlo Horwitz and Martin Myant

The European sectoral social dialogue: an uneven record of achievement? Working Paper 2015.02 / EN, FR

Christophe Degryse

The TTIP's impact: bringing in the missing issue

Working Paper 2015.01

Martin Myant M. and Ronan O'Brien

Trade union membership retention and workplace representation in Europe. Questions on the renewal of trade union organisation Working Paper 2014.10

Jeremy Waddington

About the baby and the bathwater: assessing the European Platform against Poverty

Working Paper 2014.09

Sebastiano Sabatiano and Bart Vanhercke

These publications can be downloaded free of charge from our website.

Please visit: www.etui.org/publications 